\title{
Assessment of knowledge and practices of patients with sickle cell anemia regarding the disease and preventive measures of its pain crisis
}

\author{
Afaf abd Elaziz Basal \\ Lecturer Medical Surgical Nursing, \\ Faculty of Nursing. Tanta University,

\section{Howida Abel Hakim Nafady,} \\ Internal Medicine, Faculty of Medicine, Assuit University.
}

\begin{abstract}
Background: Sickle cell disease and sickle cell anemia are serious, inherited conditions affecting the blood and various organs in the body. Sickle cell anemia is more common in people whose origins are sub-saharan Africa, India, Saudi Arabia and Mediterranean countries. Aim of the study: to evaluate the extent of knowledge and practice of patients with sickle cell regarding the disease and preventive measures of its pain crisis. Material and method: descriptive correlative design was used in the study. The subjects of the study consisted of 73 adult sickle cell anemic patients in hematological department and outpatient clinic at Assuit University Hospital. Structured questionnaire using of open ended and closed ended questions was used based on literature review. Results: More than half of patients 54.8 $\%$ had hemoglobin level of $8 \mathrm{mg} / \mathrm{dl}$. Majority of patients $86.3 \%$ had knowledge score more than $70 \%$ and nearly half of them $50.7 \%$ had satisfactory practice score ranged from $60-70 \%$.
\end{abstract} Conclusion: although patients' knowledge level in this study was high, the practical score level of nearly half of patient was satisfied. Recommendation: conduct continuing education for primary healthcare professionals to improve their ability to care for, and provide guidance to patients and their families with sickle cell disease.

Key wards: sickle cell anemia, preventive measures, knowledge, practice, pain crisis 


\section{Introduction}

Sickle cell disease and sickle cell anemia (SCA) are serious, inherited conditions affecting the blood and various organs in the body ${ }^{(1,2)}$ Sickle cell disease carries a huge psychosocial burden impacting on physical, psychological, social and occupational well-being as well as levels of independence.

In Africa, more than 200000 infants are born yearly with SCD. ${ }^{(4)}$ The prevalence of sickle-cell trait ranges between $10 \%$ and $40 \%$ across equatorial Africa and decreases to between $1 \%$ and $2 \%$ on the North African coast and less than $1 \%$ in South Africa. ${ }^{(5)}$ It is found in many parts of the world, particularly in people whose ancestors come from sub-saharan Africa, India, Saudi Arabia and Mediterranean countries; Turkey, Italy, and Greece (World Health Organization, 2006). (6) The annual diagnosis rate of sickle cell anemia in Egypt is 2,238 cases (6). Some researchers hypothesized that $\mathrm{HbS}$ gene was present among the predynastic Egyptian and they showed the presence of $\mathrm{HbS}$ in mummies (about
$3200 \mathrm{BC})$. It was also suggested that $\mathrm{HbS}$ existed among the Egyptians from ancient times and the death of King Tutankhamun was due to $\mathrm{SCA}^{.(8)}$

Nurses need to be very aware that the effects of a sickle cell crisis on different parts of the body can cause a number of complications. Sickle cell disease (SCD) affect the blood cells, causing episodes of 'Sickling' which produce episodes of pain and other symptoms. In between episodes of Sickling, people with sickle cell disease are normally well. Long-term complications can occur $(1,2,6)$ Acute painful sickle cell episodes (also known as painful crises) are caused by blockage of the small blood vessels. The red blood cells in people with sickle cell disease behave differently under a variety of conditions, including dehydration, low oxygen levels and elevated temperature or cold. Changes in any of these conditions may cause the cells to block small blood vessels and cause tissue infarction. Repeated episodes may result in organ damage. Good treatment, started 
early in life can prevent complications, so early diagnosis and specialist treatment are advised for sickle cell anemia ${ }^{(2.9,10)}$

Caring for the sickle cell patient requires a lot of nursing skill and paying strict attention to many signs and symptoms and complications of the disease. ${ }^{(3)}$ Signs and symptoms of sickle cell disease include a low number of red blood cells (anemia), repeated infections, and periodic episodes of pain. The severity of symptoms varies from person to person. Some people have mild symptoms, while others are frequently hospitalized for more serious complications. Anemia can cause shortness of breath, fatigue. The rapid breakdown of red blood cells may also cause yellowing of the eyes and skin, which are signs of jaundice. Painful episodes can occur when sickled red blood cells, which are stiff and inflexible, get stuck in small blood vessels. These episodes deprive tissues and organs of oxygen-rich blood and can lead to organ damage, especially in the lungs, kidneys, spleen, and brain. ${ }^{(2,10)}$

SCD has major social and economic implications for the affected patient as well as the family. Crises interfere with the patient's life, especially with regard to education, work and psychosocial development. Presently, there is no cure for SCD. However, cost-effective treatment exists for the pain and other aspects of the disease. The most important components of this treatment are early intervention with analgesics, antibiotics, rest, good nutrition, folic acid supplementation and high fluid intake. Treatment with hydroxyurea has reduced many of the major complications. Hydroxyurea is recommended as frontline therapy to treat adults and adolescents with moderate-to-severe recurrent pain (occurring three or more times a year). Immunizations to prevent infections, invasive procedures such as blood transfusions and surgery may be needed. ${ }^{(11,12)}$

Nurse play an important role in Patient teaching and support in long-term care of the patient. The patient and family must understand the basis of the disease and the reason for supportive care and

\footnotetext{
$r$

Vol. 5 No. 2 November, 2013
} 
ongoing screening to SCD manifestation such as

teach the patient ways to avoid crisis which include avoidance of dehydration and hypoxia, seeking medical attention to avoid respiratory tract infection and education of pain control and how to reduce stress and anxiety. Nurses should respect the patient's health beliefs and practices even when their own personal values and beliefs are different . ${ }^{(2,9,13)}$

(Okpala et al. 2002) (14) Stated that management of SCD requires a comprehensive, multidisciplinary approach, and involves managing not only the patient, but also the family as well as others who may be affected by the patient's illness. The components of comprehensive care include patient information, genetic counselling, social services, prevention of infections, dietary advice and supplementation, psychotherapy, renal and other specialist medical care, maternal and child health, orthopaedic and general surgery, pain control, physiotherapy, dental and eye care.

\section{Aim of the study:}

To evaluate knowledge and practices of patients with sickle cell anemia regarding disease and preventive measures of its pain crisis.

\section{Research questions:}

1- What is the extent of knowledge of sickle cell patients regarding disease and preventive measures of its pain crisis?

2- What is the extent of practice of sickle cell patients regarding disease and preventive measures of its pain crisis?

3- Is there is a relation between sickle cell patients' level of knowledge and practice?

\section{Subjects and method:}

Designs: A descriptive correlative design was used in this study.

Setting: the study was carried out in hematological department and outpatient clinic at Assuit University Hospital. Because Sickale cell anemia prevelence in Upper Egypt and a lot of patients from New Vally attended for treatment in this hospital. 


\section{Subjects}

A convenient sample of 73 adult sickle cell anemic patients, who accepted to be enrolled in the study during the period of three mounts from July to September 2012.

\section{Tools of the study:}

1- Structured interview questionnaire using of open ended and closed ended questions were used based on literature review. This questionnaire included four parts:

Part I: Sociodemographic data of the patient which include; age, sex, marital status, level of education, smoking history, and residence.

Part II: Patient medical history of sickle cell anemia: duration, number of hospital admission, hemoglobin level, medication, and presence of complication if any.

Part III: Patient knowledge about sickle cell anemia include: definition, causes, manifestation, complication, treatment, and precipitating factors of pain crisis.

Part IV: Patients practice related to preventive measures of pain crisis in relation to following area:
General precaution ( type of vaccination, avoiding smoking, avoiding tight clothing, contact with domestic animal, frequent dental care ,medical examination and consultation)

-Rest and activity ( type of exercise or sporting, avoiding strenuous exercise, sleep hours and rest)

Food and fluid intake ( amount and type of fluid and diet)

Travelling and places (avoiding climbing high altitude, flying without sufficient oxygen, avoiding crowded and airdraft places ).

Weather ( avoiding of exposure to extreme hot, cold and humid weather)

Medication as ( hydroxyurea, diceveral, analgesic, antibiotic and vitamin )

Psychological status ( as presence of stressors, coping with stress)

2- Anthropometric measurements: which include: height (meters), weight $(\mathrm{kg})$, body mass index $\left(\mathrm{Kg} / \mathrm{m}^{2}\right)$ The patient with body mass index of 18.5 and $24.9 \mathrm{Kg} / \mathrm{m}^{2}$ was considered to be normal weight, 25 to $29.9 \mathrm{Kg} / \mathrm{m}^{2}$ was considered over weight and 30 or 
more was considered obese and greater than $40 \mathrm{Kg} / \mathrm{m}^{2}$ was considered morbid (lewis) ${ }^{(15)}$.

\section{Method}

1- Approval of the institutional has been obtained.

2- Patient oral consent was obtained. The researchers maintained the anonymity and confidentiality of the participants after consent obtained for ethical consideration.

3- Content validity of the tool was checked by 10 experts in the in nursing and medical filed

4- A pilot study was carried out on 10 percent of patients of the study to test the applicability and visabilty of tools. The necessary modifications were done accordingly. Time taken to fill the tool lasts (15-20) minute.

5- Reliability of tool was assured by means of Cronbach Cofeffient Alpha was 0.82 .

6- According to the schedule of work in the outpatient hematologic clinic, data was collected in two days/ week four three months.
7- The researchers and nurses interviewed the illiterate patient to collect data and distributed the questionnaire sheet on the educated patient. Each patient interviewed individually in the clinic to collect data after explanation the purpose of the study and takes their oral consent.

8- The study conducted from Juli to September 2012.

\section{Scoring system}

A scoring system for patient knowledge and practice was estimated as the following. For each question for knowledge evaluation, the correct answer was given a score of 1 and the incorrect answer was given a score of zero. The same was applied for questions related to practice where the correct practice was given a score of 1 and the incorrect a score of zero based on predetermined key answer according to literature. The total score was summed up and divided by the maximum score to get the score percentage. The questions of each item were coded, computerized as poor (less 
than $60 \%$ ), satisfactory (60\% to $70 \%$ )

and good more than $70 \%$.

\section{Statistical analysis:}

The collected data were organized, tabulated and statistically analyzed using statistical package for social studies (SPSS) version 19. The mean score was calculated for the total score percentage of knowledge and practice and difference in relation to categories of determinant variables were tested using the student's $t$ test. For categorical variables the number, percentage, mean $\mathrm{X}$ and stander deviation SD were calculated. The level of significance was adopted at $\mathrm{p}<0.05$.

\section{Results :}

\section{Table (I) Distribution of the studied} sample regarding their

\section{Sociodemographic characteristics.}

Table I showed that; nearly half of patients were female and male, high percent $(45.5 \%)$ of patient aged from 1520 years. More than half $(54.5 \%)$ of patients were single and (64.4\%) of them had secondary education. The table also shows that more than half (54.8\%) of patients had body mass index which denoted low weight. High percent
(46.6\%) of patients had previous hospitalization from 1to 3 times. More than half of them $(54.8 \%)$ had hemoglobin level of $8 \mathrm{mg} / \mathrm{dl}$.

Table (2) Distribution of studied patients by their knowledge about sickle cell disease

All patients enrolled in this study mentioned that sickle cell anemia is a hereditary disease. Majority of patients (83.6\%) knew the right definition of sickle cell anemia. About half (50.7\%) of patients mentioned all manifestation of the disease. Majority of patients recognize common precipitating factors of sickle cell anemia but low percent (9.6\%) knew the importance of avoiding dealing with domestic animal as precipitating factors. All patients $100 \%$ knew the importance of premarital counseling. Majority (80.8\%) of patients knew the complications associated with sickle cell anemia include swelling and leg pain while $19.2 \%$ of patients know the all complications.

Table (3): Distribution of studied patients by their practices associated with sickle cell anemia: This table 
demonstrated that majority of patient (90.4\%) took folic acid, about two third $(64.4 \%)$ and $(65.8 \%)$ of them vaccinated by flu vaccine and ate vegetable, meat, milk and ready meal respectively. More than half $50.7 \%$ of patient drank 5- 10 cub of water daily. Regarding precaution to prevent pain crisis, about fourth 27.4 of patient preferred loose clothes, 39.7\% of patients increase fluid intake and also practiced sport and $19.2 \%$ of them practiced violent sports. Nearly half $52.2 \%$ of patients avoided high places crowded places. High percent $63.0 \%$ of patients slept enough hours. Only $27.4 \%$ made frequent dental care. Regarding precaution to decrease bone pain; more than half of the patients $52.2 \%$ used to took analgesic to reduce pain and $32.9 \%$ of them mad all measures to treat priapism

\section{Table (4): Distribution of studied} patients by their level of total score of knowledge and practice. This table showed that majority of patients (86.3\%) had total level of knowledge score of more than $70 \%$ and $32.9 \%$ of them had total level of practice of more than $70 \%$ (high or good) and nearly half of patients $50.7 \%$ had total level of practice score ranged from $60-70 \%$ (moderate or satisfactory) .

\section{Table (5): Comparison of total} knowledge score by socio-demographic factors

This table showed that there was statistical significance difference in knowledge score in relation to gender and occupation. The mean knowledge increases in male, young age, single, students, university level of education and previously hospitalized patients (more than three times) with a mean of $78.70 \pm 5.96, \quad 76.96 \pm 5.64, \quad 77.29 \pm 5.25$, $78.91 \pm 4.60, \quad 77.78 \pm 2.02, \quad 76.92 \pm 2.12$ respectively.

Table (6): Comparison of total practice score by socio-demographic factors: this table showed that there was a statistical significant difference in total practice score in relation to gender, age, marital status, job, educational level and previous hospitalization. Total practice score increase in male, increased age more than 20 years, married, and unemployed patient, educational level

$\wedge \quad$ Vol. 5 No. 2 November, 2013 
below university and previous hospitalization from 1-3 times with a mean of $67.20 \pm 4.22,67.16 \pm 4.86$, $68.97 \underline{2} .42, \quad 68.52 \pm 2.35, \quad 67.68 \pm 3.13$ respectively

Table (1) Percentage distribution of studied patients according to Socio-demographic characteristics

\begin{tabular}{|c|c|c|}
\hline Variables & Number $(\mathbf{n}=\mathbf{7 3})$ & Percentage \\
\hline Gender : & 36 & 49.3 \\
Males & 37 & 50.7 \\
Females & 34 & 46.5 \\
\hline Age in years: & 31 & 42.5 \\
$18-$ & 8 & 11.0 \\
$20-$ & & \\
$30+$ & 40 & 54.8 \\
\hline Marital status: & 33 & 45.2 \\
Single & & \\
Married & 8 & 11.0 \\
Educational level: & 47 & 64.4 \\
Illiterate & 18 & 24.7 \\
Secondary & & \\
University & 32 & 43.8 \\
\hline Job: & 41 & 56.2 \\
\hline Student & & \\
\hline Unemployed & & \\
\hline
\end{tabular}


Table 1 continues:

\begin{tabular}{|c|c|c|}
\hline Variables & Number $(\mathbf{n}=\mathbf{7 3})$ & Percentage \\
\hline \begin{tabular}{r|r|} 
Previous hospitalization due \\
to crisis:
\end{tabular} & & \\
$4-3$ & 47 & 46.4 \\
$4-5$ & 14 & 19.2 \\
$6 \pm$ & 12 & 16.4 \\
\hline Underweight $=<\mathbf{1 8 . 5}$ & 33 & 45.2 \\
\hline Normal weight $=\mathbf{1 8 . 5}-\mathbf{2 4 . 9}$ & 40 & 54.8 \\
\hline Hemoglobin level $(\mathbf{m g} / \mathbf{d} \mathbf{)}):$ & 8 & 11.0 \\
7 & 40 & 54.8 \\
10 & 15 & 20.5 \\
\hline
\end{tabular}

Table (2): percentage Distribution of studied patients according to their knowledge about sickle cell disease

\begin{tabular}{|l|c|c|}
\hline Items of knowledge & Number $(\mathbf{n}=73)$ & Percentage \\
\hline Sickle cell disease is hereditary & 73 & 100.0 \\
\hline Definition of sickle cell & 61 & 83.6 \\
\hline Normal hemoglobin level & 37 & 50.7 \\
\hline Manifestations of sickle cell anemia & 37 & 50.7 \\
\hline *Factors affecting manifestations of the crisis & 55 & 75.3 \\
\hline$\bullet \quad$ Oxygen deficit and high altitude & 66 & 90.4 \\
\hline$\bullet \quad$ Hot weather may worsen disease manifestations & 65 & 89.0 \\
\hline Dehydration morsen disease \\
manifestations
\end{tabular}




\begin{tabular}{|c|c|c|}
\hline$\bullet \quad$ Stress may worsen disease manifestations & 63 & 86.3 \\
\hline$\bullet \quad$ Inflammation and infection & 55 & 75.3 \\
\hline$\bullet \quad$ Tight cloths may worsen disease manifestations & 59 & 80.8 \\
\hline$\quad$ animals & 7 & 9.6 \\
\hline Importance of premarital counseling and testing for & 73 & 100.0 \\
prevention of sickle cell anemia & & \\
\hline *Complications associated with sickle anemia: & & 80.8 \\
Swelling and leg pains & 59 & 30.1 \\
Splenomegaly & 22 & 42.5 \\
Pneumonia & 31 & 30.1 \\
Thrombosis & 22 & 9.6 \\
Impaired vision & 7 & 20.5 \\
Gall bladder stones & 15 & 9.6 \\
Leg ulcers & 7 & 19.2 \\
All of the above & 14 & \\
\hline
\end{tabular}

*More than one answer was mentioned

Table (3): percentage distribution Distribution of studied patients according to their practices associated with sickle cell anemia

\begin{tabular}{|l|c|c|c|}
\hline Items of practice & Number $(\mathbf{n}=73)$ & Percentage \\
\hline Drugs taken: & Folic acid & 66 & \\
& Hydoxyurea & 34 & 40.4 \\
Desferal & 8 & 11.0 \\
Antibiotics & 22 & 30.1 \\
All of the above & 7 & 9.6 \\
\hline
\end{tabular}




\begin{tabular}{|c|c|c|}
\hline Vaccinations:* & & 56.2 \\
Vaccines for pneumonia & 41 & 64.4 \\
Flu vaccines & 47 & 41.1 \\
Meningitis vaccine & 8 & 11.0 \\
\hline All of the above & & \\
\hline Dietary food items: & 7 & 9.6 \\
\hline Vegetables, fruits, meat and milk & 18 & 24.7 \\
Readymade foods & 48 & 65.8 \\
Both of the above & 20 & 27.4 \\
\hline Amount of fluids taken per day: & 37 & 50.7 \\
10 or more glasses & 16 & 21.9 \\
\hline
\end{tabular}

Table 3 continue

\begin{tabular}{|c|c|c|}
\hline Items of practice & Number (n=73) & Percentage \\
\hline *Precautions to avoid sickle cell disease pains: & & \\
\hline avoidance tight clothes (general precaution) & 20 & 27.4 \\
\hline Practicing sports (activity) & 14 & 39.7 \\
\hline Practicing violent sports & 29 & 39.7 \\
\hline Increasing fluids when feeling pain or diarrhea & 38 & 52.1 \\
\hline Avoidance Climbing to high places (places) & 38 & 52.1 \\
\hline Avoidance presence in crowded places (places) & 46 & 63.0 \\
\hline Having enough sleep hours (rest) & 12 & 16.4 \\
\hline Avoidance exposed to excessive sun rays (general & & 27.4 \\
\hline Frequent dental care(general precaution) & 20 & \\
\hline
\end{tabular}




\begin{tabular}{|c|c|c|}
\hline *Precautions taken to decrease bone aches: & & 52.1 \\
Take analgesics & 38 & 41.1 \\
Take plenty of fluids & 30 & 11.0 \\
Use cold fomentations & 8 & 41.1 \\
Visit a doctor & 30 & 47.9 \\
All of the above & 35 & \\
*Precautions taken with priapism among men: & & 32.9 \\
Increase fluid intake & 24 & 32.9 \\
Visit a doctor to insert urinary catheter & 24 & 32.9 \\
Take analgesics & 24 & 32.9 \\
\hline
\end{tabular}

*More than one answer was mentioned

Table (4): Percentage Distribution of studied patients according to their level of total score of knowledge and practice

\begin{tabular}{|c|c|c|c|c|}
\hline \multirow{2}{*}{ Variables } & \multicolumn{2}{|c|}{ Knowledge total score } & \multicolumn{2}{|c|}{ Practice total score } \\
\hline & $\mathrm{N}$ & $\%$ & $\mathrm{~N}$ & $\%$ \\
\hline$<60 \%$ low & 10 & 13.7 & 12 & 16.4 \\
\hline $\begin{array}{l}60-70 \% \\
\text { moderate }\end{array}$ & 0 & 0.0 & 37 & 50.7 \\
\hline$>70 \%$ high & 63 & 86.3 & 24 & 32.9 \\
\hline
\end{tabular}

Table (5): Comparison of total knowledge score according to socio-demographic factors

\begin{tabular}{|l|c|c|c|}
\hline Variables & Total knowledge score & T & P \\
\hline Gender : & & 2.389 & $0.021^{*}$ \\
Males & $78.70 \pm 5.96$ & & \\
Females & $72.75 \pm 13.91$ & & \\
\hline Age in years: & & 0.964 & 0.339 \\
$15-$ & $76.96 \pm 5.64$ & & \\
$20 \pm$ & $74.57 \pm 14.23$ & & \\
\hline
\end{tabular}




\begin{tabular}{|l|c|c|c|}
\hline Marital status: & & 1.269 & 0.212 \\
Single & $77.29 \pm 5.25$ & & \\
Married & $73.74 \pm 15.36$ & 2.491 & $0.016^{*}$ \\
\hline Job: & $78.91 \pm 4.60$ & & \\
Students & $73.17 \pm 13.79$ & 1.565 & 0.123 \\
Unemployed & $75.00 \pm 12.68$ & & \\
\hline Educational level: & $77.78 \pm 2.02$ & 0.940 & 0.352 \\
Below university & & & \\
University & $75.00 \pm 13.74$ & & \\
\hline Previous hospitalization: & $76.92 \pm 2.12$ & & \\
$1-3$ times & & & \\
$>3$ times & & & \\
\hline
\end{tabular}

Table (6): Comparison of total practice score according to socio-demographic factors

\begin{tabular}{|l|c|c|c|}
\hline Variables & Total practice score & T & P \\
\hline Gender : & $67.20 \pm 4.22$ & 2.243 & $0.028^{*}$ \\
Males & $64.61 \pm 5.56$ & & \\
Females & & 2.360 & $0.021^{*}$ \\
\hline Age in years: & $64.43 \pm 5.01$ & & \\
$15-$ & $67.16 \pm 4.86$ & & $0.001^{*}$ \\
$20 \pm$ & & & \\
\hline Marital status: & $63.33 \pm 5.30$ & & \\
Single & $68.97 \pm 2.42$ & 5.670 & $0.001^{*}$ \\
Married & & & \\
\hline Job: & $62.50 \pm 5.64$ & 11.670 & $0.001^{*}$ \\
Students & $68.52 \pm 2.35$ & & \\
Unemployed and house wife & & & $0.001^{*}$ \\
\hline Educational level: & $68.22 \pm 3.18$ & \\
Below university & $58.73 \pm 2.31$ & & \\
University & & 6.843 & \\
\hline Previous hospitalization: & $67.68 \pm 3.13$ & & \\
$1-3$ times & $62.64 \pm 6.27$ & & \\
$>3$ times & & & \\
\hline
\end{tabular}


Tanta Scientific Nursing Journal

Discussion

$10 \quad$ Vol. 5 No. 2 November, 2013 
Sickle-cell anemia covers a wide spectrum of illness. A good knowledge of SCD especially among those with the diseases is essential in the management of this condition particularly as regards compliance with routine drugs and clinic visit. ${ }^{(16)}$ In the present study high percent $45.5 \%$ of patient aged from 15- 20 years. And about two third of them had secondary education. This was constant with the result of kofii etal 2010. in Nigerian ${ }^{(17)}$ About three-quarters of the study population were students, and less than half were late adolescent and young adult aged 18 to 20 years. Less than half $45.2 \%$ of patients were underweight according to their body mass index measurements. This result was constant with Mukherjee et al $2004{ }^{(18)}$ and Cepeda $2000{ }^{(19)}$ who stated that Females and male with sickle cell anemia maintain a lower average height and weight and body mass index than those females with normal hemoglobin. This lower than average height and weight continues until late adolescence.

High percent of patients had previous hospitalization from 1 to 3 times due to pain crisis. Tnabe et al. $2010{ }^{(20)}$ stated that participants also reported a median number of pain episodes of 3 , which has been found to be associated with more serious health outcomes.

The results revealed that more than half of patients had hemoglobin level at $8 \mathrm{mg} / \mathrm{dl}$. This is constant with World Health Organization $2006{ }^{(7)}$ that mentioned that most affected people with sickle cell disease have chronic anemia with a hemoglobin concentration of around $8 \mathrm{~g} / \mathrm{dl}$. The main problems arise from the tendency of the red blood cells to become sickle-shaped and block capillaries at low oxygen tension. Normal red blood cells live about 120 days in the bloodstream, but sickled red cells die after about 10 to 20 days. Because they cannot be replaced fast enough, the blood is chronically short of red blood cells, leading to a condition commonly referred to as anemia. ${ }^{(6)}$

In the present study, majority of patients knew definition of sickle cell anemia. More than half of patients recognized all manifestation of the disease. All patients knew the importance of premarital counseling. Majority of patients knew complications associated with sickle cell anemia. This result is agreement with Moronkola 2006 (20) as revealed that a majority of study respondents knew their genotype, had a high 
knowledge level of sickle cell disease, knew the benefits of genetic counseling, and had a positive attitude toward sickle cell disease and genetic counseling.

In the present study majority of patients had good or high level of knowledge score while only about third of them had good level of practice and nearly half of them had moderate or satisfactory practice score. But this level of the knowledge decreased in the study of Jaffer et al. in Kingdom of Bahrain $2011^{(21)}$ who stated that SCD patients mostly lack knowledge about their disease and also the result was in contrast with Al-Nasir and Niazi's study in Arabian Saudi kingdom (1997) ${ }^{(22)}$ who found that $70 \%$ of SCD patients having little or moderate knowledge about their disease. This may due to increase level of education of the patients in Egypt but lake of compliance in less than half of them. Jaffer et al. $2011^{(21)}$ mentioned that the acquisition of knowledge about a disease is important in behavior adaptation, especially if it is paired with believe that ones behavior will have positive impact on health". This statement explains the importance of knowledge to affect attitude (behaviors and believes).

In the present study, about two fifth of the patients practiced sport and fifth of them practiced violent sports. This is in agreement with Meremikwu (2006) ${ }^{(23)}$ who found that moderate exercise is generally accepted to be beneficial, especially in reducing the risk of cardiovascular disease. Moderate exercise is therefore unlikely to cause harm in people with sickle cell disease. Strenuous exercise is suspected to lead to factors that may precipitate sickle cell crisis, such as low tissue oxygen saturation, dehydration and stress.

In the present study third of male patients mad all measures to treat priapism, this agreed with Sickle Cell Association ${ }^{(24)}$ that mentioned that about $40 \%$ of males, including children, with sickle cell disease suffer from priapism. Priapism causes prolonged and painful erections that can lasts from several hours to days. If priapism is not treated, permanent partial or complete erectile dysfunction can occur.

In the present study, the mean knowledge score was increased in male, young age, single, students, university education and previous hospitalization patients. This was constant with Nwannadi. et al. $201{ }^{(16)}$ who mentioned that level of knowledge increased with increasing age, increasing level of education, marriage, and early 
commencement of regular clinic visits. Level of knowledge was noted to be significantly poor among the uneducated patients and among patients with severe disease (more than three vaso-occlusive crises requiring hospital admission or the presence of complications of SCD). Level of knowledge is a very important factor in determining the severity of SCD. Improving the level of knowledge of SCD among sufferers will help ameliorate their disease. Tanabe 2010 et al. ${ }^{(25)}$ reported that sense of self-awareness emerged as the most important strategy used by clients to manage their symptoms. Self-awareness was conveyed as being aware of certain behaviors that promote or diminish health.

In relation to knowledge of precipitating factors of pain crisis, majority of patients recognized common precipitating factors of pain crisis of sickle cell anemia but low percent of them knew the importance of avoiding dealing with domestic animal as precipitating factor. This in agreement with Stuart and Nagel $2004{ }^{(26)}$ who stated that patients should be advised to learn their trigger factors, the common ones being dehydration, infections, stress, and exposure to excessive cold.

In relation to preventive measures of pain, this study revealed that less than half of patients make all measures include taking of analgesic, increase fluid intake, make cold compressess and visting doctors for treatment. This is in agreement with Stuart and Nagel $2004^{(26)}$ who found that most pain crises are managed at home and pain relieving measures are taught to the patient, including starting analgesics quickly, keeping warm, employing relaxation techniques and drinking fluids. Clinical management includes rapid administration of analgesics (with optimal dosing and frequent repeat dosing as dictated by response, and tailored to what has worked for the patient in the past), mainly opioids, treatment of underlying infections if needed, oxygen supplementation and rest. Use of incentive spirometry and advice about deep breathing exercises is crucial, especially with presence of chest pains, to prevent complications with acute chest syndrome.

Also Tanab $2010{ }^{(25)}$ stated that Stress triggers sickle cell crises and decreases coping abilities. Learning how to effectively reduce stress through breathing, muscle relaxation, meditation, and guided imagery can assist patient in gaining a sense of control. Maintaining a balance of nutrition, rest, and exercise is also important. 
Conclusion: although patients' knowledge level in this study was high, the practical score level in nearly half of patient was satisfied. Increasing the awareness of sickle cell patients regarding this matter will potentially affect their attitudes toward crisis prevention.

\section{Recommendation:}

1- It is necessary to conduct continuing education for primary healthcare professionals to improve their ability to care for, and provide guidance to patients with sickle cell disease and their families.

2- Designing awareness programs regarding the preventive measures of sickle cell crisis is an evident need for these patients and their families.

3- qualified specialized nurses to care SCD patients should be assigment to provide direct care of these group of patients.

\section{References}

1- Mohsen A. F. El-Hazmi, Ali M. Al-Hazmi, ${ }^{*}$ and Arjumand S. Warsy, Sickle cell disease in Middle East Arab countries, Indian J Med Res. 2011 November; 134(5): 597-610.

2- Lewis S., Dirksen S, Heitkemper M, Bucher 1., Camer I. Medical Surgical Nursing. Assessment and management of clinical problems, $8^{\text {th }}$ ed, Elsevir, 2001 . 672-676.

3- Strickland OL, Jackson G, Gilead M, Mcguire DB, Quarles S. ,Use of focus groups for pain and quality of life assessment in adults with sickle cell disease. Journal of the National Black Nurses Association 2001.12:36-43

4- Makani J, Williams TN, Marsh K. Sickle cell disease in Africa: Burden and research priorities. Ann Trop Med Parasitol. 2007;101:3-14.

5- Weatherall DJ, Clegg JB: Inherited haemoglobin disorders: an increasing global health problem. Bull World Health Organ ,2001, 79(8):704-12.

6- Wasil Jastaniah, Epidemiology of sickle cell disease in Saudi Arabia, Ann Saudi Med. 2011 May-Jun; 31(3): 289-293.

7- World Health Organization: Sickle-Cell Anemia Report by the Secretariat. Fifty ninth world Health Assembly 2006. 
8- Pays JF. Tutankhamun and sickle-cell anemia. Bull Soc Pathol Exot. 2010;103:346-7.)

9- Bonds DR. Three decades of innovation in the management of sickle cell disease: The road to understanding the sickle cell disease clinical phenotype. Blood Reviews, 2005, 19:99-110.

10- Suzane C, Smeltzer, Brenda G, Janiced L, Hinkle, Kerry H, Brunner and Sudderth Text Book of medical surgical Nursing, 12 ed , 2010, Lipincott, William : 920924.

11- Saunthararajah Y, et al. Sickle cell disease: Clinical features and management. In: Hoffman R, et al. Hematology: Basic Principles and Practice. 5th ed. Philadelphia, Pa.: Churchill Livingstone Elsevier; 2009.

12- De Montalembert M, management of sickle cell disease. 2008, BMJ, 337: 1397.

13- lee 1, Askew L, Walker J,_Stephen J and Robertson A, Adults with Sickle Cell Disease: An Interdisciplinary Approach To Home Care and Self-Care Management With a Case Study, Home Healthcare Nurse, March. 2012.

14- Okpala I, Thomas V, Westerdale N, Jegede T, Raj K, Daley S, Costello-Binger H, Mullen J, Rochester-Peart C, Helps S, Tulloch E, Akpala M, Dick M, Bewley S, Davies M, and Abbs I. , The comprehensive care of sickle cell disease. European Journal of Haematology , 2002, 68:157-62.

15- Lewsis S., Dirksen S, Heitkemper M, Bucher 1., Camer I. Medical Surgical Nursing. Assessmet and management of clinical problems, eight edition, Elsevir, 2001. 944-961.

16- Nwannadi.IA, Isoa ME, Nwogoh B, Sickle Cell Disease Knowledge among Adult Patients in Benin City, Nigeria, Nigerian Hospital Practice, 2011, Vol 9, : 1-2

17- Kofi A Anie, Feyijimi E Egunjobi and Olu O Akinyanju , Psychosocial impact of sickle cell disorder: perspectives from a Nigerian setting, Globalization and Health , 2010, 6:2

18- Mukherjee M, Gangakhedkar R, Physical growth of children with sickle cell disease, Indian Journal of human Genatic, 2004, vol 10: 70-72. , 
19- Cepeda M, . Allen F, . Cepeda N, and Yang Y. Physical growth, sexual maturation, body image and sickle cell disease. National medical association journal. 2000 January; 92(1): 10-14.

20- Moronkola OA, Fadairo RA. University students in Nigeria : Knowledge, attiude toward sickle cell disease, and genetic counseling before marriage. Int $\mathrm{Q}$ Community Health Educ.2007:26(1):85-93.

21- Jaffer D, Amrallah F, Ali K, Mohammed N, Hasan R and Humood Z, Adult sickle cell diseased patients' knowledge and attitude toward the preventive measures of sickle cell disease crisis, International Journal of Nursing and Midwifery, 2009 November, Vol. 1(2): 010-018.

22- Al - Nasir F, Niazi G . Sickle cell disease: patients' Awareness and management. J. Saudi Med. 1997,18(1): 63 - 65

23- Meremikwu M . Sickle cell disease. Clin. Evid. 2006, (15):45-59

24- www.sicklecelldisease.org - Sickle Cell Disease Association of America

25- Tanabe P, Porter J, Kirkwood E, Miller S, Ahmed-Williams E, Hasse K, A, Qualitative Analysis of Best Self-management Practices: Sickle Cell Disease, $J$ Natl Med Assoc, 2010;102:1033-1041.

26- Stuart MJ, Nagel RL. Sickle-cell disease. Lancet , 2004, 364:1343-60 
Tanta Scientific Nursing Journal 